\title{
The Knowledge Of Pollution And Preservation In Relation With Environmental Care Attitude In State University Of Makassar
}

\author{
Erma Suryani Sahabuddin ${ }^{1}$, Muhammad $\operatorname{Irfan}^{2}$, Andi Makkasau ${ }^{3}$ \\ \{ermasuryani@unm.ac.id ${ }^{1}$, Irfanunm@gmail.com ${ }^{2}$ \} \\ ${ }^{1,2,3}$ Universitas Negeri Makassar, Indonesia
}

\begin{abstract}
The purposes of this study are: (1) To determine the level of students' knowledge about environmental pollution, (2) To determine the level of students' knowledge about ecosystem preservation, (3) To determine the level of students' awareness towards the environment, (4) To find out whether or not there is a positive relationship between students' knowledge about environmental pollution, the preservation of ecosystems and their caring attitude towards the environment. The population in this study was all PGSD students. The sample in this study was 86 students taken by Simple Random Sampling technique. There are 2 instruments used, namely the test instrument measuring the variable knowledge of environmental pollution and ecosystem preservation and the questionnaire instrument measuring the variable of environmental care attitude. The data analysis technique used is Pearson Product Moment correlation analysis. The results of the study show that the knowledge about pollution and and environmental care attitude of PGSD students are in the very high category, then it is obtained that the significance value meets the requirements and $r$ count is positive. It is concluded that there is a positive relationship between students' knowledge of environmental pollution and preservation and students' environmental care attitude in Elementary School Teacher Education, Faculty of Education, State University of Makassar.
\end{abstract}

Keywords: knowledge, environmental pollution, environmental care attitude 



\section{INTRODUCTION}

Environment according to Law No. 32 of 2009 is a unity of space with all objects or unity of living things including human beings and all their behaviors for the sake of sustaining the life and welfare of humans and other living things around them. Humans as environmental managers can manage and utilize every element in the environment in accordance with their functions. With the use of this environment, humans have an interdependent relationship with their environment and encourage humans to do many ways to take all the elements that exist in the environment. However, as a manager of natural resources, human has the nature of Homo Economics, namely the nature to exploit natural resources so that it can cause damage and environmental pollution.

Indonesian government regulation Number 32 article 1 point (14) Year 2009 concerning Environmental Protection and Management, explains that environmental pollution is the entry or inclusion of living things, substances, energy, and / or other components into the environment by human activities so that it transcends environmental quality standards that have been set. Pollution is a prohibited act; this prohibition is listed in Law No. 32 of 2009 in Chapter X Part 3 of Article 69 concerning the prohibition on environmental protection and management which includes a prohibition on pollution, inserting dangerous and toxic objects (B3), entering waste into environmental media, clearing land by burning and so on [1]. With regard to environmental issues, the Government takes this matter seriously. Several efforts to handle environmental problems have been carried out, one of which is through a formal education program that is legally based on a joint decision of the Minister of the Environment and the Minister of National Education in 2010. One of the objectives of this policy is to grow and develop knowledge, values, attitudes, behaviors, insight and environmental awareness of students and the community, which is pursued through the development and implementation of environmental education carried out at all lines, levels and types of education [1].

Environmental education is carried out through school education or outside school for all education majors and levels of education. One example of the implementation of environmental education in tertiary institutions is the implementation of environmental education in PGSD study program at the Faculty of Education, State University of Makassar [2]. Environmental Education (PLH) is one of the elective courses in the FSD UNM PGSD study program. Environmental Education (PLH) studied at PGSD FIP UNM has been carefully prepared to cover a variety of environmental knowledge. As stated in [3] that PLH learning materials need to be prepared carefully by integrating environmental knowledge with an insight into sustainable development, and compiled in a comprehensive, manner, and easily applied to all students. Knowledge of environmental pollution is knowledge that examines the notion of environmental pollution, the factors that cause environmental pollution, and how to overcome the occurrence of environmental pollution. So that by knowing and understanding the pollution knowledge, humans have the provision to preserve the surrounding environment through the Environmental Education (PLH) course especially in the discussion of water, soil, air, coastal and marine materials and waste. Also environmental education that has been obtained at the previous level of education shows that students of the FIP UNM PGSD already have the provision of pollution knowledge. Although it is optional, but this subject is quite popular, many students take this course especially the classes of PGSD FIP UNM year 2016.

Environmental pollution is the entry or insertion of living things, substances, energy, and / or other components into the environment by human activities so that it exceeds the established 
environmental quality standards, as stated in the Law of the Republic of Indonesia Number 32 Year 2009 concerning Protection and Environmental Management [4]. Literally, the term pollution can be interpreted as impurity, assessment, deterioration, goods or something that is contaminated by contaminants become polluted (dirty, bad) because these items or things become polluted so the quality decreases and automatically the value becomes degenerate. Moreover, if this continues again and again, many in the environment will be damaged and destroyed. Pollutants can also be interpreted as a form of environmental impairment, a disturbance of change or destruction even the presence of foreign objects in it which causes environmental elements to not function properly [5]. Based on the description above, it can be concluded that the pollution that occurs either pollution of soil, water, or air is caused by the presence of pollutants. Although these pollutants can arise naturally, but not a few of

these pollutants arise due to human behavior that exploits nature [6]. This happens because of the low attitude of caring for the environment, so that nature is treated arbitrarily. Therefore one way to reduce / overcome environmental pollution that occurs is to have an attitude of caring for the environment.

The environmental care attitude consists of three keywords, namely attitude, care, and the environment. Therefore, the nature of this attitude can be viewed from the basic assumptions of understanding attitude, care, and the environment and the interrelationships among the three. The first word is attitude which is the organization of opinions, one's beliefs about objects that are accompanied by certain feelings, and provides a basis for a person to make a response or behave in a certain way chosen. Attitude is also defined as a tendency to act like or dislike towards an object. Attitudes that are carried out continuously can form patterns of behavior. The pattern of behavior that is carried out continuously will form a personality. Based on the opinions above, it can be concluded that attitude is a way of thinking or belief of someone as outlined in the form of action in response to what is understood from a particular object. The next word is caring, caring means to heed or pay attention. A more detailed understanding was stated by [6] that "caring means treating others politely, not hurting others, sharing, wanting to be involved in community activities and caring for humans, and other creatures". In other words, caring means an attitude possessed by a human being to heed, pay attention, and treat other living beings well.

The last word on the phrase care about the environment is the environment. Usually people interpret the environment narrowly, as if the environment is only natural surroundings outside the human / individual, even though the environment actually includes all material and stimulus inside and outside the individual, both physiological and socio-cultural [7]. According to Law No. 32 of 2009, the environment is a unity of space with all objects, power, conditions, and living things, including humans and their behavior, which affect nature itself, the continuity of life, and the well-being of humans and other living things. Environmental care is the behavior of preserving the environment as well as possible, such as by maintaining, managing, and restoring, and protecting the environment [8]. Humans who care about the environment will always try to prevent damage that occurs in the surrounding natural environment, and develop efforts to repair natural damage that has already occurred. The Ministry of Environment explained that a person's environmental concern can be influenced by several factors, namely age, sex, education, marital status, ethnicity, number of household members, knowledge about the environment and attitudes towards the environment. Based on the explanation above regarding the definition of environmental concern above, it can be 
concluded that environmental care is behavior that reflects environmental concern in the form of efforts to prevent, preserve, manage and restore the environment from environmental damage. Ideally, after students gain knowledge about environmental pollution, they can form an attitude of caring for the environment. As [8]put special emphasis on learning PLH not on mastering concepts, but changing students' attitudes and mindsets to be more concerned with environmental issues, able to apply the principles of sustainability, and environmental ethics. [9]This is supported by the results of research conducted by on the influence of environmental pollution knowledge on environmental concerns of students conducted to grade VII students at Alma Ar-Ridho Middle School Semarang, the results of the study indicate that environmental pollution knowledge has a positive and significant effect on environmental concern for students of Alam Ar-Ridho Semarang Middle School. The attitude of caring for the environment needs to be instilled in every individual as early as possible; therefore it is important for PGSD FIP UNM students as prospective elementary school educators to have an attitude of caring for the environment.

\section{RESEARCH METHODS}

This research is a quantitative descriptive research with an ex-post facto type and correlational design. The population of this study was all students of the 2016 PGSD FIP UNM who have finished programming Environmental Education (PLH) courses. There were 110 students who had programmed the course. The sampling technique was simple random sampling. With the Slovin formula, selected 86 students became the research samples which were then determined by incidental means. Data on students' knowledge were measured using a modified multiple choice test instrument from the Laiyanah's study in 2017. While the data on environmental attitudes were measured using a questionnaire with a modified Likert scale from Ovi Resja Saputri's research in 2018. Then validation and reliability were tested. Validation test was carried out by experts and then field tests were conducted. There are two data analysis in this research, namely descriptive analysis and inferential analysis. Descriptive analysis was carried out with the help of SPSS 16. Presentation of descriptive analysis was carried out by looking for the categorization of students' answer scores using the following limitations:

Table 1. Limitation of Scoring

\begin{tabular}{cc}
\hline Very high & $\mathrm{X}>\mathrm{Mi}-1$ Sdi \\
\hline High & $\mathrm{Mi}>\mathrm{X} \geq \mathrm{Mi}-1$ \\
$\mathrm{Sdi}$ \\
Low & $\mathrm{Mi}+1 \underset{\mathrm{Sdi}>\mathrm{X} \geq}{\mathrm{Mi}}$ \\
Very low & $\mathrm{X} \geq \mathrm{Mi}+\mathrm{Sdi}$ \\
\hline \multicolumn{2}{c}{ Source: $[9]$}
\end{tabular}

There are three inferential analyses in this study, namely normality test, linearity test and hypothesis test. Stating the level of relationship between variables can be seen from the magnitude of the correlation coefficient or the value of $r$. The value of $r$ ranges from 0 to 1 , it 
is worth noting that, the smaller the value from 1 , the weaker the relationship between the two variables, which can be categorized by referring to opinions [10].

Table 2. Guidelines for Data Analysis

\begin{tabular}{cc}
\hline Coefficient interval & Relationship Level \\
\hline $0,00-0,199$ & Very low \\
$0,20-0,399$ & Low \\
$0,40-0,599$ & moderate \\
$0,60-0,799$ & Strong \\
$0,80-1.00$ & Very strong \\
\hline
\end{tabular}

\section{RESULTS AND DISCUSSION}

The validity used in this research is construct validity and content validity as internal validation and field validation as external validation. The number of test instruments before the validation test was 30 questions. However, due to the consideration of the representation of each indicator in the instrument, there were 4 invalid items that were corrected, so that the items used in this study were 20 items. While the questionnaire instruments obtained 25 valid statements from 41 statements provided.

Then the reliability test was conducted. Pollution knowledge reliability test results obtained alpha values of 0.827 test results which were said to be reliable instruments if the calculations show results $\geq 0.70$. Thus, the instrument for environmental pollution knowledge variables that were tested was reliable. While the test results for the environmental care attitude variable showed an alpha value of 0.884 . So it was concluded that the instrument for environmental care attitude variable that were tested was reliable. Based on the results of data analysis, scores of environmental pollution knowledge using SPSS 16 obtained data as follows.

Table 3. Description of Environmental Pollution Knowledge Data

\begin{tabular}{|c|c|c|c|}
\hline Variable & $\begin{array}{c}\text { Numbe } \\
\text { r of } \\
\text { Items }\end{array}$ & Statistics & $\begin{array}{c}\text { Data } \\
\text { Results }\end{array}$ \\
\hline \multirow{5}{*}{$\begin{array}{l}\text { Knowledge } \\
\text { of } \\
\text { Environment } \\
\text { al Pollution }\end{array}$} & \multirow{5}{*}{20} & $\begin{array}{c}\text { The } \\
\text { amount } \\
\text { of data }\end{array}$ & 86 \\
\hline & & $\begin{array}{l}\text { Minimu } \\
\text { m Score }\end{array}$ & 40 \\
\hline & & $\begin{array}{l}\text { Maximu } \\
\text { m Score }\end{array}$ & 95 \\
\hline & & Mean & 68,95 \\
\hline & & Median & 70,00 \\
\hline
\end{tabular}




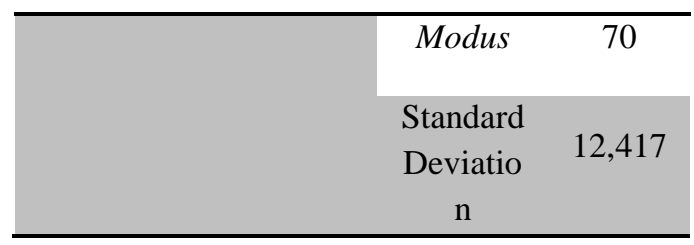

The standard deviation is a reflection of the mean deviation in the mean data. Standard deviations can illustrate how much data variation. If the standard deviation is smaller than the mean, this shows that the mean can be used as a representation of the whole data. Conversely, if the standard deviation is greater than the mean, this shows that the mean is a poor representation of the overall data.

Based on the descriptive analysis results above, it is known that the mean is greater than the standard deviation data, which is $68.95>12,417$, so it can be concluded that the mean value is a good presentation and can be used for the whole data. Furthermore, data classification table was made to find out the category of knowledge on environmental pollution variables to be very low, low, high and very high by using the ideal average value (Mi) and the ideal standard deviation (SDi).

Table 4. Classification of Environmental Pollution Knowledge Data

\begin{tabular}{lllll}
\hline $\begin{array}{l}\mathbf{N} \\
\mathbf{0}\end{array}$ & $\begin{array}{l}\text { Catego } \\
\text { ry }\end{array}$ & Interval & $\begin{array}{l}\text { Frequen } \\
\text { cy }\end{array}$ & $\begin{array}{l}\text { Perce } \\
\text { ntage } \\
(\%)\end{array}$ \\
\hline $\mathbf{1}$ & $\begin{array}{l}\text { Very } \\
\text { high }\end{array}$ & $\mathrm{X}>66,7$ & 51 & 59,3 \\
$\mathbf{2}$ & High & $\begin{array}{l}66,7>\mathrm{X} \geq \\
50\end{array}$ & 30 & 34,9 \\
$\mathbf{3}$ & Low & $\begin{array}{l}50>\mathrm{X} \geq \\
33,3\end{array}$ & 5 & 5,8 \\
$\mathbf{4}$ & $\begin{array}{l}\text { Very } \\
\text { low }\end{array}$ & $\mathrm{X}<33,3$ & 0 & 0 \\
\hline
\end{tabular}

Table 5. Description of Data on Environmental Care Attitudes

\begin{tabular}{|c|c|c|c|}
\hline Variable & $\begin{array}{l}\text { Number } \\
\text { of Items }\end{array}$ & Statistics & $\begin{array}{c}\text { Data } \\
\text { Result } \\
\text { s }\end{array}$ \\
\hline \multirow{3}{*}{$\begin{array}{l}\text { Attitude to } \\
\text { Care for the } \\
\text { Environmen } \\
\text { t }\end{array}$} & \multirow[t]{3}{*}{25} & $\begin{array}{c}\text { The amount } \\
\text { of data }\end{array}$ & 86 \\
\hline & & $\begin{array}{l}\text { Minimum } \\
\text { Score }\end{array}$ & 40 \\
\hline & & $\begin{array}{l}\text { Maximum } \\
\text { Score }\end{array}$ & 92 \\
\hline
\end{tabular}




\begin{tabular}{cc}
\hline Mean & 73,33 \\
Median & 75,00 \\
Modus & 75 \\
& \\
\hline $\begin{array}{l}\text { Standard } \\
\text { Deviation }\end{array}$ & 9,123 \\
\hline
\end{tabular}

Based on the table of descriptive analysis results, it is known that the mean data is greater than the standard deviation data which is $73.33>9,123$. The standard deviation is a reflection of the mean deviation in the mean data. Standard deviations can illustrate the number of data variation if the value of standard deviation is very high. By using the ideal average value (Mi) and the ideal standard deviation (SDi).

Table 6. Classification of Data on Environmental Care Attitudes

\begin{tabular}{|c|c|c|c|c|}
\hline No & $\begin{array}{c}\text { Categor } \\
\mathrm{y}\end{array}$ & $\begin{array}{c}\text { Interva } \\
1\end{array}$ & $\begin{array}{c}\text { Frequen } \\
\text { cy }\end{array}$ & $\begin{array}{c}\text { Perce } \\
\text { ntage } \\
(\%)\end{array}$ \\
\hline 1 & $\begin{array}{l}\text { Very } \\
\text { high }\end{array}$ & $X>75$ & 44 & 51,2 \\
\hline 2 & High & $\begin{array}{l}75>X \\
\geq 62,5\end{array}$ & 33 & 38,4 \\
\hline 3 & Low & $\begin{array}{c}62,5> \\
X \geq \\
50\end{array}$ & 8 & 9,3 \\
\hline 4 & $\begin{array}{l}\text { Very } \\
\text { low }\end{array}$ & $X<50$ & 1 & 1,2 \\
\hline
\end{tabular}

Based on the table above, it can be seen that from 86 PGSD FIP UNM students studied in 2016, 77 students were in the category of high and very high in term of their environmental care attitude; only 1 student had very low environmental care attitude This shows that the 2016 PGSD FIP UNM students have a good environmental care attitude. The results of hypothesis testing in this study are as follows.

Table 7. Correlation Test Results

\begin{tabular}{ccc}
\hline Correlation & Significance & r_calculate \\
\hline $\begin{array}{c}\text { Knowledge of } \\
\text { environmental }\end{array}$ & 0,000 & 0,438 \\
pollution with an & & \\
attitude of caring for & & \\
the environment & & \\
\hline
\end{tabular}


If the standard deviation is smaller than the mean, this shows that the mean can be used as a representation of the whole data. Conversely, if the standard deviation is greater than the mean, this shows that the mean is a poor representation of the overall data. Because the data analysis results shows that the mean value is far greater than the standard deviation value, it can be concluded that the mean value is a good presentation and can be used for the whole data. Furthermore, it can be made a data classification table of environmental care attitude variables to find out the very low, low, and high categories. The results of the linearity test calculations based on the table above indicate that the significance value obtained is less than $5 \%$ significance i.e smaller than 0.05 . And the calculated $r$ value obtained is positive. So based on this analysis, it can be concluded that there is a positive relationship between knowledge of environmental pollution with environmental attitudes of PGSD FIP UNM students in 2016. By seeing that the significance value is smaller than the $5 \%$ significance level and the calculated $r$ value indicates a positive value, the hypothesis alternatives (HI) in this study were accepted. The closeness of the relationship can be seen in the magnitude of the coefficient of correlation with the following guidelines table [10].

Table 4.10. Data Analysis Guidelines

\begin{tabular}{cc}
\hline Coefficient interval & Relationship Level \\
\hline $0,00-0,199$ & Very low \\
$0,20-0,399$ & Low \\
$0,40-0,599$ & Is \\
$0,60-0,799$ & Strong \\
$0,80-1.00$ & Very strong \\
\hline \multicolumn{2}{c}{ Source: $[10]$}
\end{tabular}

The results of the analysis with Pearson Product Moment gives the calculated $r$ value (correlation coefficient) of 0.438 . Based on this analysis, it can be concluded that the level of relationship between environmental pollution knowledge and environmental care attitude of PGSD FIP UNM students is in the medium category.

\section{DISCUSSION}

1. Knowledge of Environmental Pollution

The results of research conducted on 86 PGSD students of the Faculty of Education at Makassar State University in 2016, showed that the level of student knowledge about environmental pollution was in the very high category. This concludes that the 2016 PGSD Faculty of Education, State University of Makassar has had good environmental pollution knowledge. As Sephardi's opinion [11], there is a need for knowledge, education, and training as well as scientific development of environmental management so that environmental problems can be overcome. One of the knowledge is that students get through the lecture process of Environmental Education (PLH) especially in the discussion of water, soil, air, coastal and marine materials and waste.Good pollution knowledge can also be obtained from various other factors such as books, radio, television, magazines, posters, and newspapers. Pollution knowledge obtained through these factors is obtained with the help of the senses, this is in accordance with the understanding of knowledge which says that knowledge is the work of the senses. Besides parents, friends, and personal experiences of students can also be 
a source of knowledge. Based on the average scoring of research data of environmental pollution knowledge variable shows that the indicator "Detecting the factors that influence environmental pollution" is an instrument indicator of environmental pollution knowledge variable with the highest score compared to other indicators. So it can be concluded that the indicator "Detecting the factors that influence environmental pollution" is the factor that most influences the environmental pollution knowledge of PGSD students at the Faculty of Education, Makassar State University in 2016. While the least influencing knowledge of environmental pollution is the indicator "Detecting the impact of various kinds of environmental pollution ". This is one of the reasons that there are still students who sometimes litter, they do know that trash is a cause of pollution but they still litter because they do not know the adverse effects of these actions. Good knowledge of environmental pollution will affect students' caring attitude towards the environment. This is in line with the opinion [12] which states that there are several factors that influence a person's attitude, one of which is the Knowledge factor.

\section{Attitude to Care for the Environment}

One of the most important attitudes for the welfare of humanity is the attitude of caring for the environment. According to [13] the attitude of caring for the environment is an attitude of protecting the environment, preventing and repairing environmental damage. The attitude of caring for the environment is an attitude that must be possessed by every human being, bearing in mind the environment not only acts as a place to live, but also acts as a supporter of various human activities. Activities to maintain environmental conditions that can support life are the obligations of all individuals living in this world without exception, including students. As stated by [14] that students are expected to have knowledge, care, and skills as well as a positive attitude towards the environment. In order for students to have a caring attitude towards the environment, first the teacher as an educator must have an attitude of caring for the environment.

Therefore, it is very important for PGSD students as prospective educators in elementary schools to have good environmental care attitudes. The results of research conducted on 86 PGSD students of the Faculty of Education at Makassar State University in 2016, showed that the level of environmental care attitude of students was in the very high category. So it can be concluded that the PGSD students of the Faculty of Education at the State University of Makassar in 2016 have a good environmental care attitude. This Environmental Education (PLH) course programmed successfully instills an attitude of caring for the environment to students.

This result is supported by Mustakin [15] that educational institutions should play their role in shaping environmental awareness. And there needs to be character building on the environment within students. Based on the average scoring of research data, the variable knowledge of Environmental pollution shows that the indicator "Wise in using natural resources" is an indicator of the instrument of environmental care attitude variable with the highest score compared to other indicators. So it can be concluded that the indicator "Wise in using natural resources" is the factor that most influences the attitude of environmental care PGSD students of the Faculty of Education Makassar State University in 2016. While the least influential indicator on the attitude of caring for the environment of students is the indicator "Respect for health and hygiene ".

This shows that even though the 2016 generation of PGSD FIP UNM students have a wise attitude in using natural resources, they are still lacking in respecting the health and hygiene that is around them. The attitude of caring about the environment of students can be obtained 
through their understanding of knowledge about the environment, one of which is knowledge of environmental pollution. Where, this is in line with the explanation of the ministry of environment that a person's environmental care can be influenced by several factors, namely age, sex, education, knowledge of the environment and attitudes towards the environment.

3. Relationship between Environmental Pollution Knowledge and Attitudes to Environmental Care

The attitude of caring for the environment is influenced by several factors, one of which is the knowledge of environmental pollution. As [6]put special emphasis on PLH learning that is not about mastering concepts, but about changing attitudes and mindsets of students to be more concerned with environmental issues, able to apply the principles of sustainability, and environmental ethics.

Bloom in [16] stated that there are 3 (three) components of ability that determine the quality of a person's attitude and behavior, namely: cognitive component, affective component, and psychomotor component. A person's knowledge determines his attitude and behavior, the better his knowledge, the better his attitude and behavior. Knowledge is also one of the predisposing factors for the change from attitude to behavior. Before becoming a behavior there will be a change in attitude that comes from knowledge.

Knowledge and attitude are two factors that can be observed or assessed and are likely to be intervened. So it can be concluded that if good knowledge will have a good attitude too. Individuals who have knowledge of environmental pollution will have good environmental care attitudes. This is reinforced by the results of research on the relationship between environmental pollution knowledge with environmental care attitudes that have been carried out. The results of research conducted on 86 PGSD students of the Faculty of Education at Makassar State University in 2016, concluded that there was a positive relationship between knowledge of environmental pollution with an attitude of caring for the environment of PGSD students at the Faculty of Education at Makassar State University in 2016, with the level of closeness of the relationship being at medium category. Thus the hypothesis in this study that reads "There is a positive relationship between knowledge of environmental pollution and attitudes of caring for students of PGSD FIP UNM 2016 for the environment" is proven.

This research is in line with research [17]that there is a positive relationship between knowledge of pollution and students' caring attitude towards the environment. The positive relationship between knowledge of pollution with students' caring attitude towards the environment to the environment based on this study is shown from statistical analysis that produces a positive correlation value. This means that there is a positive relationship between knowledge and students 'concern for the environment, where the better the knowledge of pollution, the higher the students' concern for the environment. By conducting research on the relationship between knowledge of environmental pollution and this attitude of caring for the environment, the results of this study can be used as a basis for the development of values for environmental care attitudes, especially PGSD students. One of the ways to care about students' environment needs to be developed, one of which can be done by increasing the knowledge of student environmental pollution. With the attitude of caring for the environment in PGSD students, it is hoped that when they become teachers they can play a role in instilling environmental care in their students. 
4. The relationship between students' knowledge about environmental pollution, preservation of ecosystems with an attitude of concern for the environment

A positive relationship between knowledge of environmental pollution with an attitude of caring for the environment for PGSD students of the Faculty of Education, Makassar State University class of 2016, with the level of closeness of the relationship is in the medium category.

Although the results of this study indicate a positive relationship between environmental pollution knowledge and environmental care attitudes of PGSD students at the Faculty of Education, Makassar State University in 2016. However, the value of the relationship obtained in this study indicates a moderate level of relationship, meaning that in this study environmental pollution knowledge is not the only thing that can affect attitude. There are other factors that can affect students' environmental care attitudes. Among them are environmental factors, both the influence of circumstances, and the influence of people who are considered important such as friends

\section{CONCLUSION}

Based on the results of research conducted on 2016 PGSD FIP UNM students, it can be concluded that environmental pollution knowledge and environmental care attitudes of PGSD FIP UNM 2016 students are in the very high category. The results of this study also show that there is a positive relationship between knowledge of pollution with an attitude of caring for the environment of PGSD FIP UNM students in 2016, with the strength of the relationship being in the moderate category.

\section{REFERENCES}

[1] A. Warner, C. Eames and R. Irving, "Using Social Media to Reinforce Environmental Learning and Action-Taking for School Students," International Electronic Journal of Environmental Education, vol. 4 , no. 2, pp. 83-96, 2014.

[2] N. A. Rahman, "Knowledge, Internal, and Enviromental Factors on Enviromental Care Behaviour Amoung Aboriginal Students in Malaysia," International Journal of Enviromental \& Science Education, p. 18, 2016.

[3] E. S. Sahabuddin, . G. . D. Dirawan and M. , "The Implementation of Environmental Education Based on Action-Portfolio to Improve the Learning Participation of the Student," Research Journal of Applied Sciences, vol. 12, no. 1, pp. 73-77, 2017.

[4] G. T. T. a. H. E. M. Bas, " Emphasizing Local Features for Effective Enviromental Education: Environmental Attitudes of Elementary School Students Living in Ancient Halicarnassus," vol. 22, no. 2, pp. 119-132, 2011.

[5] B. P. Statistik, " INDIKATOR PERILAKU PEDULI LINGKUNGAN HIDUP 2014 PERILAKU PEDULI," vol. 2014, 2014.

[6] K. BASRI, E. . S. Sahabuddin and M. K. Tok, "Car Pollution Measurement: A Study On 'Health'environment," Pollution Research, vol. 34, no. 3, pp. 497-502, 2015.

[7] B. G. Bergman, "Assessing Impacts of Locally Designed Environmental Education Projects on Students' Environmental Attitudes, Awareness, and Intention to Act," Environmental Education Research, vol. 22 , no. 4, pp.480-503 , 2016. 
[8] Y. H. d. R. O. Adisendjaja, Pembelajaran Pendidikan Lingkungan Hidup: Belajar dari Pengalaman dan Belajar dari Alam., Bandung: UPI, (2013).

[9] D. W.P, Perilaku peduli lingkungan ditinjau dari aspek pemahaman tentang lingkungan, (2011).

[10] C.-S. Lai, "A Study of Fifth Graders' Environmental Learning Outcomes in Taipei," International Journal of Research in Education and Science, vol. 4 , no. 1, pp. 252 $262,2018$.

[11] Y. H. d. R. O. Adisendjaja, Pembelajaran Pendidikan Lingkungan Hidup: Belajar dari Pengalaman dan Belajar dari Alam, Bandung: UPI, (2013).

[12] M. Genc, "The Project Based Learning Approach in Enveromental Education,," Journal International Research, pp. 105-117, 2015.

[13] M. Djemari, Teknik Penyusunan Instrumen Tes dan Nontes., Yogyakarta: Mitra, 2008.

[14] Sugiyono, Metode Penelitian Kuantitatif, Kualitatif dan R\&D., Bandung: Alfabeta., 2015.

[15] A. Z. D. M. Suarja, " Hubungan Antara Pengetahuan Alam Dan (PALH) Dengan Perilaku Siswa Dalam Pengelolaan Kebersihan Lingkungan. Jurnal Serambi Scientia," vol. 2 , no. 2, p. 136, 2014.

[16] M. N. Purwanto, Psikologi Pendidikan, bandung: Remaja Rosdakarya, 2014.

[17] E. S. Sahabuddin, "Model Pembelajaran Pendidikan Lingkunga Hidup Berbasis E Ducational - Portofolio.," no. 95-114., "2015) 
